\title{
RESEARCHING TERRORISM IN SOUTH AFRICA: MORE QUESTIONS THAN ANSWERS
}

\section{Hussein Solomon \\ Department of Political Studies and Governance, University of the Free State}

\begin{abstract}
South Africa confronts a tangible terror threat in the form of some terrorists targeting the country itself, whilst others find it useful as an operational base to strike at targets elsewhere. Far from attempting to provide a comprehensive study of this phenomenon, this article aims to point out the pitfalls of researching terrorism in the South African context. This largely stems from mixed signals emanating from the South African government as well as the reluctance on the part of Pretoria's securocrats to answer questions pertaining to terrorism. Two reasons are advanced to explain this: incompetence and political correctness. Such mixed signals, it is argued, also confuse the security apparatus of the state itself. This, in turn, serves to frustrate counter-terror efforts.
\end{abstract}

\section{Introduction}

On the evening of the $25^{\text {th }}$ August 1998, the Giddings family of Hampshire, England, entered Planet Hollywood in Cape Town. Tony Giddings (43), his wife Mandy (40), children Laura (13) and Jacob (8), and grandparents Brian (70) and Iris (68) were laughing as they entered the restaurant. Shortly after they entered, the pipe bomb placed on the bar's foot rail exploded. The result of that explosion was to cast a long shadow on the lives of the Giddings family. Laura lost a leg, Jacob still has

Scientia Militaria, South African Journal of Military Studies, Vol 40, Nr 2, 2012, pp. 142-165 doi: $10.5787 / 40-2-1000$ shrapnel in the fluid around his spine, shrapnel also injured Brian Giddings and an artery in his leg was severed, and Tony Giddings has to use a cane to get around. ${ }^{1}$ And yet, they were amongst the fortunate ones. Two other people 
were killed in this terrorist atrocity. Their crime was to be having dinner at Planet Hollywood, possibly the most iconic representation of the American culture in Cape Town.

The bombing of Planet Hollywood also resulted in my quest to understand the phenomenon of terrorism in South Africa. Unfortunately, my study of terrorism in this country has raised more questions than answers on account of the ambiguous nature of government responses. Frankly, one is unsure whether the ambivalent and contradictory responses from the post-94 Pretoria government emanate as a result of incompetence or of political correctness or a combination of the two.

Incompetence bedevils the state security apparatus in the terrain of counterterrorism. For example, in August 2009, the prosecution of two PAGAD members Faizel Waggie and Shahied Davids - for the attempted bombings of the Keg and Swan restaurant in November 2000 was quietly abandoned. This case tells us quite a bit about the incompetence of the state security apparatus. It would seem that the case was abandoned since conversations of the accused were bugged illegally and that the police had lied under oath. More importantly, the two alleged accomplices of Waggie and Davids - Yusuf and Fahiema Enous, who had turned state witness were assassinated while in witness protection. Neither was this the first time that witnesses were killed. Ebrahim Gallie, who was to testify in another PAGADrelated trial was abducted and later shot and killed. Needless to say, this case, too, had to be dropped. ${ }^{2}$ Here lies the rub - if potential witnesses are aware of how unsafe witness protection is, will they really come forward to testify? And, if such witnesses do not come forward, can cases be successfully tried? Could the state's reticence to answer questions not be on account of its incompetence - and the embarrassment that may arise from it?

Political correctness characterises the highest levels of South Africa's political establishment and undermines the fight against the scourge of terrorism. Former Minister of Intelligence, Ronnie Kasrils, on one occasion stated,

... we guard against a rising international hysteria which serves to portray all Muslims as potential targets. The cry of "a terrorist in every Madrassah" echoes the "red under the bed" and "swart gevaar" [black danger] phobia of the Cold War and the apartheid era. We must never repeat such witch-hunts in our country. ${ }^{3}$

This ideological blindness on the part of Kasrils refuses to recognise the qualitative difference between the armed struggle against apartheid and the current 
global jihadist scourge; indeed, it besmirches the noble struggle against the apartheid regime. Whilst there was the infamous Magoos Bar bombing, attacks on soft targets were not countenanced by the African National Congress (ANC) leadership. ${ }^{4}$ The idea that one targets innocent diners in a restaurant or passengers on a bus was anathema to the ANC. In this way, the ANC was able to maintain the moral high ground. Even more important were the limited goals of the ANC - a democratic, non-racial South Africa - compared to the global ambitions of radical Islamists who seek to establish a global Muslim caliphate. ${ }^{5}$

The legacy of apartheid looms large over South African policymakers both domestically and internationally - and it should. However, when policymakers examine everything through the lens of apartheid, they inevitably get it wrong since other actors are motivated by other compulsions. As Anneli Botha ${ }^{6}$ has cogently argued, "As a nascent democracy, South Africa is obsessed with protecting basic rights, rights that would be exploited by international terrorists working in tandem with local militants." Are we then surprised that, despite all the terrorist activity taking place on South African soil, so few individuals have been arrested for terrorism? What Pretoria seems to have forgotten is that these same terrorists that they are treating with kid gloves are willing to deny the most fundamental of all rights - that of the right to life! Kurt Shillinger of the South African Institute for International Affairs (SAIIA) is also of the opinion that the reason why Pretoria has been showing little desire to investigate its own Muslim community is because it does not want to alienate it. $^{7}$

Whether through incompetence or political correctness, the reality is that the intrepid researcher is confronted with the challenge of attempting to understand terrorism in South Africa whilst being confronted with reticence on the part of government officials to answer questions as well as ambiguous and contradictory responses. Far from attempting to provide a comprehensive study of terrorism in South Africa, this article rather focuses on the challenges confronting researchers attempting to study the phenomenon in this country. The pitfalls of undertaking research on terrorism will be explained by way of specific case studies. The first is the case of the alleged Muizenberg cell.

\section{The mystery of the Muizenberg cell}

Just before dawn on the 25January 2008, Police Superintendent Noel Zeeman led his officers in a raid on two homes in Muizenberg, outside Cape Town. Three of the men who were targeted were Mustafa Mohamed Jonker, his brother-in- 
law Omar Hartley, and Sedick Achmat. They stood accused as being part of a group planning to overthrow the government by means of blowing up specific targets. The men had been downloading material on how to make explosives. Other members of the group were Mahomed Davids, Abdul Rasheed Davids and Rafiek Osman. Despite the nature of the items seized in the raid, and the gravity of the charges high treason, terrorism, conspiracy to commit murder and unlawful possession of firearms, ammunition and explosives - none of the men were arrested. Indeed, the Davids brothers subsequently left the shores of South Africa.

It would seem that it was the men's internet activity - visits to various jihadi websites together with a tip-off - that prompted the raids. Zeeman was to claim in court papers that in the raid, police discovered chemicals, computers as well as videos containing brutal beheadings. ${ }^{8}$ According to police explosives expert, Captain Bester, the explosives the men were in possession of - hydrochloric acid, acetone and peroxide, which were hidden under the bed of one of the accused were, according to the formula downloaded from the Internet, and were to be used to make improvised explosive devices (IEDs). ${ }^{9}$ The accused men in turn referred to the chemicals as "pool cleaner, paint remover and bleach". ${ }^{10}$ As for the internet downloads from jihadi websites, Jonker stated,

When I visited these Jihadi sites, I downloaded everything. This information that I downloaded, is information that everyone has access to and is freely available. They are legal to download. The pictures downloaded reveal how Muslims throughout the world are being killed and how they are killing those who are attacking them. ${ }^{11}$

Jonker and Hartley went to court to challenge the search and seizure warrants issued by the magistrate, with their lawyer demanding the full disclosure of the contents of the affidavit, which led to the warrant being issued. ${ }^{12}$ Zeeman, meanwhile, asked the judge to place a "gag" on certain parts of the affidavit used to grant the search warrants on account of it containing "sensitive information". ${ }^{13}$ By March 2008, however, when the case went to court, presiding judge, Justice Bennie Griesel, told the men's lawyers that he had not seen the state's opposing papers. Subsequently, it emerged that a deal was cut between the lawyer of the accused men and the state that resulted in the case being dropped and the material seized in the raid handed back to the men ${ }^{14}$.

For researchers attempting to come to analyse the risk posed to South Africa by terrorists, situations like these raise more questions than they provide answers. 
The state seemed confident of their case, yet they refused to file opposing papers and then cut a deal with the accused before the case went to court. So, did Zeeman want to protect his "very reliable source"15 that had tipped him off about the Muizenberg cell? And was he afraid that his source would have been compromised if the affidavit was made public? Or, on the other hand, could the accused be innocent? According to their lawyer, the raids were part of a conspiracy by a "... Third Force to spread fear of Muslim culture and justify the establishment of US military and Israeli secret services bases in South Africa". ${ }^{16}$

However problematic we may believe the Muizenberg case/cell was, worse was still to come if we examine the strange case of the two South Africans caught in an Al Qaeda safe house in Pakistan.

\section{The enigmatic Ganchi-Ismail duo}

On 10 July 2004, Dr Feroze Abubaker Ganchi and Zubair Ismail travelled to Pakistan together. The latter ostensibly went to pursue his Islamic education and the former to do welfare work. ${ }^{17}$ They entered Pakistan with passports that were exact copies of those seized in British anti-terror raids in London. ${ }^{18}$ Once in Pakistan they were assisted by local contacts ${ }^{19}$ to get to a house in Mohhalluh Islam Nagar ${ }^{20}$. At this house, there were Islamists from Kenya and Sudan, as well as senior Al Qaeda operative, Ahmed Khalfan Ghailani. Ghailani was alleged to have been responsible for purchasing the truck that was used as the vehicle bomb on the US embassy in Dar es Salaam in Tanzania in 1998 in which more than 200 people were killed. On 16 December 1998, a New York court indicted Ghailani for his role in this terrorist act. As a result, Ghailani was on the list of the Federal Bureau of Investigation's (FBI) 22 most-wanted terrorists. ${ }^{21}$

Following a tip-off, ${ }^{22}$ Pakistani security forces surrounded the house and a fierce 12-hour gun battle ensued. Fighting only ceased after the men inside the house had run out of ammunition and Pakistani commandos broke down the wall and roof of one of the rooms and fired tear gas canisters into the house. Given the length of the gun battle and its ferocity as well as the subsequent confession from the South Africans, the Pakistani authorities believed that they were "trained terrorists". Indeed, the Pakistani newspaper Dawn also stated that the South Africans had received training in Afghanistan and Iran. ${ }^{23}$ Upon entering the house, the Pakistani security services discovered ten Kalashnikov rifles, pistols, hand grenades, laptop computers, chemicals, and atlases and maps. ${ }^{24}$ Pakistan's Law Minister Raja 
Basharat stated that all of the twelve men arrested were operatives in Osama bin Laden's Al Qaeda network ${ }^{25}$.

Media reports indicated that both South Africans confessed to Pakistani authorities that their mission was to carry out terror attacks in South Africa. Amongst the alleged targets were the Carlton Centre, the Johannesburg Stock Exchange, Parliament, the Union Buildings, the Victoria and Alfred Waterfront, the Sheraton Hotel and the US embassy in Pretoria ${ }^{26}$.

What is most confusing in this saga is the South African government's reaction. When news first broke, the Department of Foreign Affairs (now Department of International Relations and Co-operation) spokesperson, Ronnie Mamoepa, essentially questioned whether Ismail and Ganchi were indeed South African. He pointed out that there were several cases of forged South African passports being used by international criminals and terrorists. ${ }^{27}$ When it emerged that they were indeed South African citizens and the circumstances of their arrest came to light, then Deputy Foreign Affairs Minister, Aziz Pahad, later stated, "With the involvement of Ghailani, the case has taken on a more serious security aspect. What was earlier a foreign affairs issue is now an international security one." ${ }^{28}$ In August 2004, South Africa's National Intelligence Agency (NIA) sent a team to Pakistan to question the two South Africans personally. The subsequent statements from then NIA Director-General Vusi Mavimbela after NIA had interviewed the men were most interesting,

We wanted to know whether it was true that there were plans to attack South Africa. This was all we wanted to know and we found that there was no evidence of such plans ...We are not interested in why they are in Pakistan - South Africa is our only interest. ${ }^{29}$

As in the case of the Muizenberg raid, there are more questions than there are answers. Why did these men travel with passports that were exact replicas of the one seized in a British anti-terror raid in London? Why were these men caught in an Al Qaeda safe house in Pakistan with a senior Al Qaeda terrorist? Why was NIA not interested to find out the reasons for this? Were the Pakistani government officials lying when stating that the men were planning to attack targets in South Africa? If so, what was the motivation? On the other hand, what assurances did Mr Mavimbela have that these men were not going to strike at targets in South Africa? Was there a deal cut between the state and the suspects as happened in the Muizenberg case? 
I continued to reflect on these questions I continued to mull about with no answers to be found and even more so following subsequent developments. The men eventually returned to South Africa only to have the media probing any connection between the two men and the alleged $\mathrm{Al}$ Qaeda terrorists from Syria and Jordan that the police had deported that year. ${ }^{30}$ It subsequently emerged that indeed both Ganchi and Ismail were in contact with these men and had met them on several occasions in April 2004 shortly before they were arrested. ${ }^{31}$ They would meet at a mosque in Laudium, Pretoria as well as at a madressah where Ismail attended Islamic education classes. Neither was this the first time that Ganchi and Ismail were in contact with foreign Islamists. Three years prior to these events of 2004, Ismail travelled to the United Kingdom where he met Islamists from London and Manchester. ${ }^{32}$ It also emerged that both South Africans were recruited by a mystery Al Qaeda recruiter simply named "Ahmed". ${ }^{33}$

Worse was still to come when intelligence officers in the South African Police Service (SAPS) confirmed that South Africa was to be targeted by Ganchi and Ismail thus contradicting Mr Mavimbela and the NIA's own statement. According to one police agent, they had been following the suspects and never doubted that they were targeting South Africa for terrorism purposes. ${ }^{34}$ Yet NIA's Mavimbela repeatedly denied that South Africa was being targeted by terrorists, "In terms of the information we have as security services, we have got no information that any particular installation in South Africa is being targeted by al Qaeda, or any international terrorist organisation. ${ }^{35}$ According to Ronald Sandee though, in his testimony to the US Congress, upon returning to South Africa and being interrogated by South African officials, both Ganchi and Ismail admitted to targeting South Africa for terror attacks. ${ }^{36}$ So why was Mavimbela so adamant that South Africa was not at risk?

More questions emerged. Did the SAPS know about the threat for over a year and a half ${ }^{37}$ - they were actually following the suspects - and not tell NIA about it? More importantly, why was Ganchi and Ismail allowed to fly out from South Africa via Dubai to Pakistan on travel documents that were problematic at best? Ganchi and Ismail were again caught and detained in Guinea in December 2004 when they tried to cross the border into Sierra Leone. Here Ganchi was using the alias Dr Mohammed Nazzal. ${ }^{38}$ A few months later, on 7 March 2005, Ganchi and Ismail together with Muhsin Fadhi (aka Abu Sami from Kuwait) and Abu Ubaysah al-Turki (aka Ubaida Ubeyde from Turkey) were arrested when they tried to cross the border between Indonesia and East Timor. ${ }^{39}$ I found myself asking the 
same questions in 2009 when Ganchi was detained by Egyptian authorities en route to Gaza. $^{40}$

Are Ganchi and Ismail guilty of what they have been accused of or are they hapless travellers just being at the wrong place at the wrong time? What accounts for the contradictory statements coming from the security apparatus of the state? Is there a threat to South Africa or not? As a researcher on the terror threat posed to South Africa, one has to negotiate this labyrinth of contradictory statements and interpret it to the best of one's ability.

\section{I am South African - please do not arrest me!}

Besides Ganchi and Ismail, South Africans are increasingly getting picked up around the world - an indication of how the country is viewed by the rest of the world. On 19 July 2004, Farida Goolam Mohamed Ahmed was arrested at McAllen airport whilst trying to board a flight to New York from Texas on account of her not being able to provide a visa to prove her legal travel within the US. Four days later, the charges became more serious. She was charged with entering the US illegally, falsifying information and falsifying a passport. It then emerged that Ahmed entered the US illegally from Mexico, across the Rio Grande. Ahmed also carried a large amount of cash in US dollars, British pounds, Mexican pesos and gold South African Krugerrands. ${ }^{41}$ US authorities were also suspicious of the amount of travelling she had done - having flown at least 250 times to different destinations. ${ }^{42}$ Authorities were also concerned that the route she took to enter the US was chosen to deliberately cover her tracks. Ahmed flew to Dubai, then to London, then to Mexico City and from there she illegally crossed the Rio Grande River into Texas. ${ }^{43}$ At the time, the United Kingdom and Mexico did not require visas for South Africans. $^{44}$

We do not know the purpose of Ahmed's travels nor why she entered the country illegally or, indeed, why she had such large amounts of foreign currency on her. Her family, in South Africa, also refused to talk about it saying that their lawyer had advised them to talk about Ahmed's "visit overseas". ${ }^{45}$ What we do know is that the Americans did investigate her to ascertain whether she had ties with terror groups $^{46}$ and after she had changed her plea to guilty on all charges of being an illegal immigrant, ${ }^{47}$ she was subsequently deported to South Africa. The reticence on the part of her family to comment is also mirrored in the reticence on the part of the US government, which declined to say why she illegally entered the country or whether she had ties with terrorist groups. ${ }^{48}$ All that a senior US Customs and 
Border Protection official would say is that South Africa is "... becoming a breeding ground for terrorists". ${ }^{49}$ Again, this constitutes a challenge to researchers in trying to understand this case. Was it simply a case of illegal immigration or something more sinister?

In August 2006, Shafique Ur-Rehman, a Pakistani, who married a South African woman and now residing in Cape Town, arrived at London's Heathrow Airport. Here immigration officials detained him, his luggage was searched, he was then photographed and he was put back on a flight to South Africa without his passport having been returned. According to media reports, British authorities said he was being sent back to South Africa on account of him having too much money and lying about whom he was going to visit - something which Ur-Rehman admitted to. ${ }^{50}$ Upon returning to South Africa, Ur-Rehman was taken to the Ravensmead police station where he was questioned by two plainclothes policemen on whether he had ties with PAGAD or Al Qaeda. He was subsequently released. According to South African Home Affairs spokesperson, Mantshele Tau, this was merely a case of mistaken identity - Ur-Rehman's surname was the same as that of a man wanted by British authorities on terror charges. ${ }^{51}$ If this is the case, why the large amounts of cash and why did he lie about whom he was visiting? Again, this is something difficult to assess.

In September 2006, Ebrahim Essop Desai and his son, Zakharriya, were travelling to the US when they were stopped in Senegal by a South African Airways official and told they could not proceed to the US and had to return to South Africa. The same happened to Ismail Mulla - also being stopped in Senegal - then having his luggage searched and being fingerprinted and photographed. He was also asked if he had been to Afghanistan and if he knew how to make bombs. ${ }^{52}$ Again, it is difficult to assess what the real meaning of all this is. Did the respective authorities have specific information on these individuals or was it part of a general concern about South African travel documentation given the widespread corruption in the Department of Home Affairs?

In August 2008, Mufti Hussain Bhayat of Lenasia and Haroon Saley of Azaadville, were detained at Entebbe International Airport in Kampala by Uganda's Joint Anti-terrorism Task Force, suspected of being involved in terrorist activities. A week after their arrest, Uganda's National Security Council decided to deport the two South Africans. On announcing their deportation to South Africa, Ugandan Army spokesperson Major Paddy Ankunda said, "After investigations, the Council established that the men are not good people and should leave the country."53 Again, 
it is difficult to assess what is going on in the murky world of intelligence but clearly not being "good people" in the eyes of the National Security Council of Uganda needs to be seen in security terms.

\section{Davids and the case of three pipe bombs}

Similarly, government responses are either not forthcoming or contradictory on a number of issues. For instance, in December 2006, Shahied Davids was caught with three pipe bombs in the boot of his car. According to police at the time, he was to attack various targets around Cape Town. However, a year later, all charges against him were withdrawn without explanation. ${ }^{54}$ Why were charges withdrawn? Why were the police - so confident about their case having caught the suspect redhanded - suddenly reticent to respond to questions posed? For researchers, this constitutes a conundrum. How could one possibly research the extent of terrorism in the country when faced with the reticence of authorities to comment?

\section{The mystery of Ibrahim Tantouche}

The case of Ibrahim Tantouche, the Libyan national, is also indicative of the poor legal structure in South Africa and the way global terror networks may exploit this. Tantouche was deported from Australia after entering that country with a false South African passport. Once in South Africa, in November 2003, he applied for asylum. ${ }^{55}$ Libya, however asked for his extradition on the grounds that he stole gold which was then used to fund terror activities. Interpol, too, was looking for Tantouche. However, in November 2005, the extradition proceedings against Tantouche were struck from the Pretoria magistrate's court's roll on account of the fact that the state had not received presidential consent to process Libya's request for the extradition of Tantouche. Such consent is mandatory in a case like this where South Africa has no extradition treaty with Libya. ${ }^{56}$

Whether it was an oversight on the part of the South African Presidency or not, the reality is that the South African legal system is just not working. Tantouche, after all, was given refugee status even though he had lied, bribed and fraudulently obtained a South African passport. Moreover, it emerged that Tantouche had also obtained fraudulent passports from Pakistan, Morocco, Indonesia and Malaysia. ${ }^{57}$ Whilst in Malaysia, Tantouche had meetings with members of the Libyan Islamic Fighting Group (LIFG) and whilst in South Africa, he had meetings with members of the Algerian-based Salafist Group for Preaching and Combat (GSPC) which now forms an important part of Al Qaeda in the Islamic Maghreb (AQIM). ${ }^{58}$ Tantouche 
was also instrumental in setting up various financial fronts whilst in South Africa. The case of Abd al-Muhsin al-Libi, also known as Ibrahim Tantouche, ${ }^{59}$ also points to how terrorists secure financing in South Africa. He set up two Al Qaeda financing fronts - the Afghan Support Committee and the Revival of Islamic Society. ${ }^{60}$ Both operated as charities that raised money for orphans; however, in reality the orphans were either dead or non-existent.

Were these the actions of a Libyan political dissident fearing for his life, as he claims, or something more sinister? Security mandarins in Pretoria are unforthcoming with answers - a veritable nightmare for any researcher.

\section{Paramilitary camps}

Reports of paramilitary training camps have also surfaced periodically. As early as 1996, Israel lodged a formal complaint with the South African government regarding the existence of five Hezbollah training camps in the country. ${ }^{61}$ In March 2007, Barry Gilder, the former head of the National Intelligence Coordinating Committee (NICOC), acknowledged the possible existence of small-scale training camps used by terrorists in the country. ${ }^{62}$ Most of these trainers it would seem came from Pakistan, Somalia, Bangladesh and Jordan. In the same month, a Johannesburg magazine exposed the existence of a jihadi facility outside Port Elizabeth, where instructors provided students with combat training, as well as training in illegal high-calibre handguns, $\mathrm{R} 1$ rifles and AK-47s. ${ }^{63}$ The camp became operational in the mid-1990s with Nazier Desai as the head trainer and his cousin Ahmed Seddick Desai running the finances ${ }^{64}$.

More worrisome is the existence of terrorist training camps on isolated farms- with the knowledge of certain people in the South African government. ${ }^{65}$ Clearly, these government officials believe that South Africa will not be targeted by these elements. Unfortunately, the available evidence does not support such wishful thinking. When the US, for example, was targeted on foreign soil, as in the East African US embassy bombings, there were 5000 casualties - overwhelmingly local Kenyans and Tanzanians. ${ }^{66}$ Likewise, the redoubtable Richard Cornwell has noted that there is nothing preventing South Africa's own citizens from becoming "collateral" in the pursuit of other targets. ${ }^{67}$ Unfortunately, this belief that South Africa will not be targeted could also account for the fact that, despite monitoring these camps for a number of years, no action has been taken. 
Like any cancer left alone, these camps started to spread, and by May 2010, there were reports that operational militant training camps were established in several provinces in South Africa, ${ }^{68}$ and that these had links with other camps outside the country. By June 2010, South African journalists were in possession of correspondence with former and active trainees of these militant camps. ${ }^{69}$ This, in turn, raises two important questions. First, if journalists knew about the training camps, and the nature of the training, and were also in contact with militants, why would the South African government have not been as well? Second, if policy makers do have such information, why do they not shut it down? Is it once again the belief that South Africa is immune from such attacks?

\section{The regional conundrum}

It is imperative to examine the regional context in which South Africa exists. Andrew Holt, for instance, raises the possibility that South Africa could be forming the basis of the territorial crux of Islamists from Sudan to the Cape of Good Hope. ${ }^{70}$ Such a view would make sense on three counts. First, South Africa with its relatively sophisticated transport, communication and business and banking infrastructure could more easily be used as a “... logistical and operational hub by Pan-Islamic extremists" ${ }^{\prime 11}$ than the poorly developed Sudan or the non-functioning Somalia. Second, given the fact that organised crime syndicates (especially those involved in narco-trafficking) were already regional in character by the 1990s, and that these had a working relationship with Islamists, syndicates could piggyback on criminal networks already operating in the region. ${ }^{72}$ Third, terror organisations such as Hezbollah were already regionally anchored from Abidjan in the Ivory Coast to Kinshasa in the Democratic Republic of the Congo to Johannesburg, South Africa. ${ }^{73}$

By 2004, reports of terrorist training camps in Mozambique started to circulate in the intelligence community. ${ }^{74}$ Six years later, in 2010, at least three training camps were identified in Nampula and Tete provinces of Mozambique. One of these camps is run by Somalis, another by Pakistanis and a third by Indians and Bangladeshis. ${ }^{75}$ In the process, the nexus between the global, regional and national dimensions of Islamist terrorism are demonstrated quite well.

The regional dimensions of South Africa's terrorism problems were also seen in September 2009. In that month, the US embassy in Pretoria, its consulates across the country and the offices of the US Agency for International Development (USAID) were compelled to close following reports of a terror plot targeting American interests in South Africa. The immediate catalyst for this was the US 
killing a senior Al Qaeda operative, Saleh Ali Saleh, in Somalia. According to media reports, ${ }^{76}$ intercepted cell phone communication indicated that a Somali group, the Al Shabaab, plotted to attack US interests in South Africa in revenge.

The Al Shabaab cell was based in Khayalitsha township, just outside Cape Town. However, this cell was clearly an advanced cell preparing the ground for a region-wide operation. The cell phone intercepts revealed, furthermore, that $\mathrm{Al}$ Shabaab had also established cells in Mozambique, and that come 2010, when South Africa hosted the 2010 Fifa World Cup Soccer tournament, these cells would move en masse to South Africa to strike at various US-linked interests. The fact that these cells had access to military hardware from the former Eastern bloc added capacity to motivation. Meanwhile, from neighbouring Botswana, the Sunday Standard reported that Al Qaeda operatives, using various used car dealerships as their cover, were also preparing for terrorist attacks during the World Cup. ${ }^{77}$ The fact that both Al Shabaab and Al Qaeda subscribe to radical Salafist ideology and the fact that Al Shabaab recently pledged their loyalty to Al Qaeda suggest that these two developments were inter-related and part of one larger plot to target the 2010 Games.

Given the abundance of information emanating from a variety of sources, in May 2010 Ronald Sandee, the Research Director of the NEFA Foundation warned the US Congress of a credible terror threat confronting South Africa. ${ }^{78}$ In response, Minister of Police Nathi Mthethwa dismissed the NEFA report stating, "There is no threat to South Africa as we speak now." ${ }^{79}$ However, Sandee's presentation also drew on data from South African police intelligence reports that contained detailed information about terror training camps. Sandee goes on to note, "The fact that officials [now] refute this is reason to believe that they don't have their apparatus under control. ${ }^{" 80}$ As researchers working in this area, we are faced with a situation where a paper draws from police intelligence reports having detailed information about terror training camps in South Africa whilst the Minister of Police is unaware of it! What are we to make of this? Moreover, whilst countries like Botswana took active steps to dismantle the terror infrastructure in their country, the South Africans did nothing. Why?

\section{Ambiguity in South Africa's counter-terror response}

Increasingly, ambiguity has come to characterise South Africa's counterterror response. This ambiguity arises from the gap between the dictates of the political correctness approach - which was alluded to earlier - and a harsh reality that contradicts this. Several examples of this ambiguity exist. 
Former National Police Commissioner Jackie Selebi informed the media of various Al Qaeda operatives who were planning to stage terror attacks during April 2004. A few months later though, in August 2004, first government spokesman Joel Netshitenzhe, then National Intelligence Agency (NIA) Director-General Vusi Mavimbela and Ray Lalla, Head of SAPS Crime Intelligence denied that South Africa has been targeted by Al Qaeda, but when they were pressed for further information, they refused to provide any, stating "operational security" precluded them from doing so. ${ }^{81}$ So which is it - do we listen to the National Police Commissioner or to the head of the police's Crime Intelligence Unit? Moreover, if South Africa is not targeted, what operational security considerations would there be which would prevent one from sharing this with the media? These denials also contradicted what Pakistan's Gujarat Chief of Police, Raja Manwar Hussain, had asserted at the time following their arresting two South Africans (Ganchi and Ismail) in Pakistan - that they were plotting attacks in their home country.

In another example of double-speak, Intelligence Minister Ronnie Kasrils in October 2004 denied media reports that South Africa was being used as a base for Al Qaeda operations. However, in August 2005, he warned that Al Qaeda was possibly trying to set up networks in southern Africa and that it would be easy for them to attack harbours. ${ }^{82}$ So, does the 2005 statement from Mr Kasrils supersede the 2004 statement? Is $\mathrm{Al}$ Qaeda using this region as a base for their operations? Is it a yes or a no? It certainly cannot be both!

Following the closure of the US embassy and consulates as well as the offices of USAID in September 2009 following the Al Shabaab threat, South Africa's National Police Commissioner (now General) Bheki Cele said that police were investigating the threat, but he added that the police had not ruled out the possibility of a hoax. In the same statement, though, he said that police were pursuing some people and there would be arrests. ${ }^{83}$ So, if the threat was a possible hoax, why are the police pursuing suspects and why was there to be imminent arrests? Moreover, if the threat was a hoax or "not credible" as Cele subsequently asserted, why did it worry the South African Secret Service (SASS) enough to send agents to Kenya and Somalia to gather their own intelligence on Al Shabaab ${ }^{84}$ This hoax and not-so-credible threat also prompted NIA to conduct raids on a Somali organisation in Johannesburg in November 2009. ${ }^{85}$ This so-called hoax and not credible threat did, however, also result in a joint operation involving senior police officers, members of NIA and American agents, which resulted in the arrest of 
militants linked to extremists in Somalia and Mozambique and from there these were linked to $\mathrm{Al}$ Qaeda lieutenants in Afghanistan and Pakistan. ${ }^{86}$

Pretoria's ambiguous response to terrorism also extends into the international sphere. In October 2006, during his meeting with the Indian Prime Minister Manmohan Singh, former President Thabo Mbeki spoke of the need for international co-operation in the area of counter-terrorism. When such co-operation, however, is needed from the South Africans, they baulk. In January 2007, when South Africa was informed that the US intended to place two South Africans - the Dockrat cousins - on the UN Security Council's list of terror suspects, South Africa was vehemently opposed to this. ${ }^{87}$ Needless to say, relations between Washington and Pretoria soured. These incidents raise the question of whether South Africa is prepared to walk the talk in the global fight against terrorism or not. Put differently, is South Africa a credible partner in the fight against terrorism?

\section{Conclusion}

Terrorism is a global and globalising phenomenon. We see this in the form of Lebanese Hezbollah being able to operate in South America, Asia and Africa. Similarly, Somali-based Al Shabaab is increasingly globalising its operations from its recruitment drives among the Somali diaspora in Minneapolis to it sending its fighters to get trained in Afghanistan, Pakistan and Yemen. Moreover, its targets are similarly global - from Danish cartoonists to US interests in South Africa. South Africa, too, has not only to confront its own terror networks but foreign networks as well. A perusal of Appendix 1 suggests the enormity of the challenge posed. The need for good and reliable information is the building block on which all counterterrorism strategies are built. Where such information is contradictory, or unreliable because it is tainted with political correctness or where information is simply not forthcoming it results in poor analysis and failed counter-terror strategies.

What is interesting in my discussions with South Africa's securocrats, is that many of these are as confused as I am as to whether there is a terrorism threat to South Africa and the strategy to be pursued. This is unacceptable. If we are to prevent another Planet Hollywood bombing on South African soil then the mixed signals have to stop, the political correctness has to stop, and greater clarity in policy and greater effort in implementation are needed. The terrorists we are confronting share none of our ambivalence on their destructive goals. We cannot hope to defeat them and protect our citizens if we continue to play ostrich. 


\section{Appendix 1}

\section{Chronology of catastrophe}

October 2010 - SAPS raids home of Mogamat Munier Martin, arms, ammunition and chemicals which could be used to make explosives are confiscated

July 2010 - Interpol and SAPS net suspects in Pretoria attempting to sell highly radioactive material suspected to be used in "dirty bomb"

June 2010 - Zimbabwe police arrest two Pakistani men heading to South Africa, one of them allegedly under an international arrest warrant for terrorism

June 2010 - Further reports of terror training camps in SA - journalists in possession of correspondence from former and current trainees of militant camps

May 2010 - Reports of operational militant training camps in several provinces in SA

May 2010 - Pakistan and Somali militants running training camps in northern Mozambique - trainees being infiltrated across the border into SA

May 2010 - SA Department of Home Affairs announces a new movement control system to regulate the movement of people in and beyond the country's borders

May 2010 - Reports indicate that corruption at CIPRO funds global terror networks

April 2010 - Al Qaeda in the Arab Maghreb threaten to attack the 2010 World Cup tournament in SA

February 2010 - Media reports new purge in SA's intelligence community

January 2010 - Jamaican cleric Sheikh Faisal deported from Kenya whose authorities accuse him of recruiting suicide bombers to target the 2010 World Cup tournament in SA

October 2009 - NIA, SAPS and American agents launch joint operation to foil plot to attack 2010 World Cup - arrests made and those arrested had links with extremists in Somalia and Mozambique

October 2009 - Interpol and SAPS team up to ensure safety of FIFA 2010 World Cup

October 2009 - Reports from Botswana point to Al Qaeda operating using second hand car dealerships as a front to strike at the World Cup

October 2009 - Jeff Maqetuka appointed Director-General of the State Security Agency promises intelligence shake-up

September 2009 - US closes all its embassies and consulates and the offices of USAID in response to terror threat from Al Shabab

September 2009 - PAGAD revives its branches in Grassy Park, Strand, Paarl and Mitchell's Plain 
September 2009 - Man with fake Pakistani passport arrested at OR Tambo International Airport. Interpol says criminal act about to be perpetrated in SA March 2009 - FIFA General Secretary Jerome Valcke calls a crisis evaluation committee meeting in Johannesburg to discuss 2010 FIFA World Cup security following terror attack on the Sri Lankan cricket team in Pakistan

January 2009 - Explosive device found in rubbish bin in Laudium, outside Pretoria 2009 - 378 illegal explosions occur in SA

July 2008 - Zambian authorities capture and deport Haroon Rashid Aswat to Britain. Aswat evaded South African surveillance when he left SA to enter Zambia March 2008 - Intelligence Minister Ronnie Kasrils warns of Al Qaeda members seeking refuge in SA and possibly attempting setting up networks

March 2008 -State cuts deal with Muizenberg coup plot accused January 2008 - Raid on Muizenberg (Cape Town) homes of suspected terrorists August 2008 - Two South Africans detained at Entebbe Airport by Uganda's Joint Anti-terrorism Task Force

March 2007 - Reports of terrorists with links to Afghanistan, Pakistan and Iraq spending time in South Africa

March 2007 - Concern expressed by SA government official of terrorists using South African banks and identity documents

March 2007 - Report of a paramilitary training facility in Port Elizabeth

January 2007 - US lists two South African cousins for UNSC lists of terror suspects whilst putting them on US Treasury Department's list of Al Qaeda supporters

2007 - Alleged Al Qaeda financier Ibrahim Ali Tantouche given asylum in SA

December 2006 - Yusuf and Fahiema Enous killed whilst under witness protection

December 2006 - Shahied Davids arrested in possession of three pipe bombs, a year later all charges against him withdrawn without explanation

November 2006 - Alleged Taliban member Khalid Rashid arrested and subsequently extraordinarily renditioned

July 2006 - Alleged ringleader of plot to down seven trans-Atlantic flights from Britain arrives in London via South Africa

August 2005 - Scorpion and US DEA joint operation discover clandestine cell in Cape Town which specialises in shipping Al Qaeda operatives from Afghanistan and Pakistan to the United Kingdom

December 2004 - Reports that South Africa has become an important operational and logistical hub for pan-Islamist terror networks appear

November/December 2004 - South Africans arrested in Pakistan and southern Afghanistan for having links with Al Qaeda 
October 2004 - Ringleader of Al Qaeda cell in South Africa evades capture and is on the run in Africa

October 2004 - Media reports point to local militants having contact with Osama bin Laden and his Al Qaeda network

October 2004 - CIA reports that second and third tier of Al Qaeda leadership hiding in Pakistan, Iraq and South Africa

August 2004 - South African police intelligence agents confirm terror plot to target South Africa with Gauteng province the first to be targeted

August 2004 - South African government expresses fear that Al Qaeda operatives may be hiding in Muslim theological schools

August 2004 - Influx of theological students to SA from countries like Pakistan where some theological schools were closed down out of fear that they were a breeding ground for terrorists

July 2004 - Two Pretoria residents, Zubeir Ismail and Dr Feroz Ganchi, arrested in Pakistan caught in an Al Qaeda safe house with senior Al Qaeda commander Ahmed Khalfan Ghailani

June 2004 - Alleged Al Qaeda banker and Libyan national, Ibrahim Tantouche, fights his extradition to Libya in court, wanting to stay in South Africa

June 2004 - South African Department of Home Affairs link with Al Qaeda operatives captured in London confirmed

June 2004 - Minister of Home Affairs confirms Al Qaeda operative using South African passports

May 2004 - South African police capture suspected Al Qaeda operatives from Jordan and Syria

May 2004 - British Select Committee on Foreign Affairs recommends that greater assistance be provided to SA to combat international terrorism

2004 - Reports of active terrorist camps in Mozambique surface

July 2003 - Israeli Security Service declares that there is "recognisable Hamas activity" in SA

2003 - Tunisian Ihsan Garnaoui arrested in Germany for attempting terror attacks in the country - planning for it done whilst Garnaoui was in SA

2002 - NIA and FBI warn that SA was being used to raise funds and as a safe haven for international terrorist organisations

2002 - Wall Street Journal expresses concern over Al Qaeda presence in SA

February 2000 - Abduction and later killing of state witness Ebrahim Gallie

October 1999 - Khalfan Khamis Mohamed, wanted for his role in the US Embassy bombings in East Africa is caught in Cape Town

2001 - PAGAD designated as a Foreign Terrorist Organisation by the US State Department 
November 2000 - Faizel Waggie and Naziem Davids arrested allegedly just after they planted a bomb in front of the Keg and Swan restaurant in Durbanville, Cape Town; seven years later case was closed

1998-2000 - PAGAD blamed for a series of bombings, including the 25 August 1998 Planet Hollywood blast

October 1999 - Khalfan Khamis Mohamed, part of Al Qaeda cell that attacked US embassies in East Africa, arrested in Cape Town

1998 - President Thabo Mbeki asks NIA to report on Hamas and its activities in SA

1997 - Al Qaeda established foothold in South Africa

1997 - Hamas representatives visit SA assessing paramilitary camps - these deemed to be basic and needed to be upgraded

1996 - Israel lodges a formal complaint to the SA government of the existence of five Hezbollah training camps

December 1995 - PAGAD established

1995 - Cassiem appointed head of the Islamic Unity Convention, an umbrella organisation representing 250 South African Muslim groups

1992 - Al Aqsa International Foundation established in SA

1992 - Hamas active in SA

1990s - Qibla members fight with Hezbollah in South Lebanon

1984-1985 - Islamic Liberation Movement of Azania established

1980s - Criminal networks develop across Southern Africa

1980s - Qibla members get military training from Libya and Pakistan

1980 - Qibla is established by Achmed Cassiem

\section{Endnotes}

${ }^{1}$ Kemp, Y. "I warned them. They ignored me". Cape Argus. 13 May 2003. 1.

2 Brummer, S \& Sole, S. "Did top cops rig PAGAD case?" Mail and Guardian. 25/33. 21 August 2009. 2-3.

${ }^{3}$ Shillinger, K. “Al Qaeda in southern Africa”. Armed Forces Journal. 2006. <http://www.afji.com/2006/02/1813653/> Accessed on 20 March 2008.

4 Truth and Reconciliation Commission. "Holding the ANC accountable". The TRC Report 6/5, Ch. 3. 2003. 649. <http://www.info.gov.za/otherdocs/2003/trc/5_3.pdf> Accessed on 5 May 2008.

${ }^{5}$ Solomon, H. Pakistan and the legacy of Maulana Maududi. Occasional Paper No. 9/2009. International Institute for Islamic Studies, 2009, 2.

${ }^{6}$ Botha, A. "Pagad: A case study of radical Islam in South Africa". Terrorism Monitor 3/15. 28 July 2010. 11. 
7 "South Africa's growing terrorist hideout". News24.com. 6 September 2005. <http://www.news.24.com/SouthAfrica/News/SA-a-growing-terroristhideout-20050905> Accessed on 20 March 2008.

8 "State cuts deal with Muizenberg coup plot accused". SABC News. 25 March 2008. <http://www.sabcnews.com/south_africa/crime1justice/0,2172,166418,00.ht ml> Accessed on 6 May 2009.

9 “Internet download leads to bust". Independent Online. 23 March 2008. <http://www.iol.co.za/news/newsprint.php?art_id_=vn20080323115841846

${ }^{10}$ Ibid. C64> Accessed on 25 June 2008.

11 "Web site downloads lead to terror accusations". Legalbrief Today. 26 March 2008. 〈http://www.legalbrief.co.za/article.php?story=2008032608341632> Accessed on 4 September 2010.

12 "Internet downloads lead to bust" op. cit.

13 "Internet downloads lead to bust". The Sunday Tribune. 23 March 2008. 2.

${ }^{14}$ Breytenbach, K. "Police to return 'terror raid' material". Cape Times. 26 March 2008.

<http://www.iol.co.za/index.php?set id=1\&click id=15\&art id=vn2008032 $\underline{6052235418 \mathrm{C} 855953}>$ Accessed on 31 August 2010.

15 Breytenbach, K. "Cape terror suspects fight case in court". Cape Times. 25 March 2008.

<http://www.iol.co.za/index.php?set id=1\&click id=13\&art id=vn2008032 5054519104C525056> Accessed on 31 August 2010.

${ }^{16}$ Breytenbach, "Police to return terror raid material" op. cit.

${ }^{17}$ De Lange, D. "Cape Terror suspects fight case in court". Beeld. 28 July 2010. <http://www.iol.co.za/index.php?set_id=1\&click_id=13\&art_id=vn2008032 5054519104C525056> Accessed on 31 August 2010.

${ }^{18}$ Hosken, G. "SA targeted by terrorist - police". Pretoria News. 4 August 2004. <http://www.iol.co.za/index.php?sf=174\&set_id=1\&click_id=13\&art_id=vn 20040804052518353C413655> Accessed on 3 September 2010.

${ }^{19}$ Naeem, J \&Hosken, G. "Did SA pair confess to Pakistani officials?”. The Star. 4 August 2008.

${ }^{20}$ Steyn, T. "SA men 'trained terrorists"”. News24.com. 26 July 2004. <http://www.news24.com/SouthAfrica/News/SA-men-trained-terrorists20040726> Accessed on 31 August 2010.

21 “Al Qaeda suspect co-operating”. News24.com. 29 July 2004. <http://www.news24.com/World/News/Al-Qaeda-suspect-co-operating20040729> Accessed on 31 August 2010.

${ }^{22}$ Naeem \& Hosken op. cit.

23 Steyn op. cit.

${ }^{24}$ Ibid.

${ }^{25}$ Meldrum, A. "Terror link to South Africa after gun battle". The Guardian. 6 August 2004. 
<http://www.guardian.co.uk/world/2004/aug/06/pakistan.terrorism $>$

Accessed on 4 September 2010.

${ }^{26}$ Naeem \& Hosken op. cit.

27 "SA men's fate unknown". News24.com. 29 July 2004. <http://www.news24.com/World/News/SA-mens-fate-unknown-20040729> Accessed on 4 September 2010.

${ }^{28}$ De Lange, D. "New twist in Al Qaeda arrests". News24.com. 30 July 2004. <http://www.news24.com/SouthAfrica/News/New-twist-in-alQaeda-arrests-20040730> Accessed on 4 September 2010.

29 "NIA clear SA men in Pakistan". News24.com. 21 August 2004. <http://www.news24.com/SouthAfrica/News/NIA-clears-SA-men-inPakistan-20040821> Accessed on 4 September 2010; Basson, A. "SA 2 Pakistan must decide". News24.com. 23 August 2004. <http://www.news24.com/SouthAfrica/News/SA-2-Pakistan-must-decide20040823> Accessed on 4 September 2010.

${ }^{30}$ Schmidt, M, Akim, K \& Badat, NY. "SA pair accused of terrorism fly home". The Star. 18 December 2004. 1.

${ }^{31}$ Hosken op. cit.

${ }^{32}$ Naeem, J \& Hosken, G. "The hunt is on for Al Qaeda recruiter". Cape Argus. 4 August 2004.

${ }^{33}$ Naeem \& Hosken, "Did SA pair confess..." op. cit.

${ }^{34}$ Hosken op. cit.

${ }^{35}$ Monare, M, Hosken, G \& SAPA. “Government insists SA is not under threat”. The Mercury. 5 August 2008.

<http://www.iol.co.za/index.php?sf=116\&set_id=1\&click_id=13\&art_id=vn 20040805051704165C941309> Accessed on 4 September 2010.

${ }^{36}$ Sandee, R, Research Director of the NEFA Foundation."Target South Africa". Presentation to the US Congress, 26 May 2010, 4.

${ }^{37}$ Naeem \& Hosken, "The hunt is on ... "op. cit.

${ }^{38}$ Sandee op. cit., p. 5.

39 Ibid.

40 "SA, Egypt in talks over doctor". News24.com. 26 January 2009. <http://www.news24.com/NEWS24v2/components/Generic/News24v2 prin t_PopUp> Accessed on 26 January 2009.

41 "Does Al Qaeda have access to South African passports?". The Star. 28 July 2004.

<http://www.iol.co.za/index.php?set_id=1\&click_id=15\&art_id=vn2004072 8151953911C466683\&singlepage $=1>$ Accessed on 1 September 2010.

${ }^{42}$ Molwedi, P, Fabricius, P \& SAPA-AP. "SA woman held in US not Al Qaeda". Sunday Argus. 1 August 2004.

<http://www.iol.co.za/index.php?set_id=1\&click_id=13\&art_id=vn2004080 $\underline{1121844592 C 146559 \& \text { singlepage }=1>\text { Accessed on } 1 \text { September } 2010 .}$ 
43 "South African woman pleads innocent in immigration case". AP. 21 August 2004. <http://www.highbeam.com/doc/1P1-98176423.html > Accessed on 4 September 2010.

${ }^{44}$ Sperry, P. "Homeland insecurity: US warns of al-Qaeda from South Africa Inspectors on high alert for operatives using nation's passports". WorldNetDaily. 6 August 2004. <http://www.wnd.com/?pageId=25969> Accessed on 1 September 2010.

${ }^{45}$ Molwedi, Fabricius \& SAPA-AP op. cit.

46 "Does Al Qaeda have access ..." op. cit., p. 3.

47 "SA woman pleads guilty in US immigration case". Cape Times.28 September 2004.

$<$ http://www.iol.co.za/index.php?set_id=1\&click_id=15\&art_id=vn2004092 8064520402C402162> Accessed on 4 September 2010.

48 "South African woman arrested for illegal entry into United States sentenced to time served, will be deported". AP. 9 December 2004. <http://www.highbeam.com/doc/1P1-103239676.html> Accessed on 4 September 2010.

${ }^{49}$ Sperry op. cit.

${ }^{50}$ Hawker, D. "SA man held as 'terror suspect' in UK". Cape Argus. 16 August 2006.

$<$ http://www.iol.co.za/index.php?set_id=1\&click_id=13\&art_id=vn2006081

${ }^{51}$ Ibid. 6095833529C914642> Accessed on 1 September 2010.

${ }^{52}$ Gallagher, C. "We need travel treaty with US, say US Muslims". Cape Argus. 28 January 2007.

<http://www.iol.co.za/index.php?from=rss_News\&set_id=1\&click_id=0\&ar t $\mathrm{id}=\mathrm{in} 20070128094949330 \mathrm{C} 819040>$ Accessed on 4 September 2010.

${ }^{53}$ Mukasa, H. "South African detainees to be deported". The New Vision. 29 August 2008. 〈http://www.newvision.co.ug/D/8/13/646957> Accessed on 1 September 2010.

${ }_{55}^{54}$ Brummer \& Sole op. cit., p. 2.

${ }^{55}$ Ellis, E. "Terrorist banker fighting to stay in South Africa". Cape Argus. 20 April 2004. 2.

56 "Halt to extradition proceedings". News24.com. 28 November 2005. <http://www.news24.com/SouthAfrica/News/Halt-to-extraditionproceedings-20051128> Accessed on 4 September 2010.

${ }^{57}$ Mbanjwa, X. "He did it out of fear for his life". Pretoria News. 13 September 2007.

${ }_{58}^{58}$ Sandee op. cit., p. 5.

${ }^{59}$ Templeton, A. "SA keeps an eye on 'Bin Laden's banker'”. Independent Online. 2 August 2005.

$<$ http://www.iol.co.za/index.php?set_id=1\&click_id=15\&art_id=vn2005080 2135007903C957531> Accessed on 20 March 2008; Templeton, A. 
"Uncovering the life of London bomb suspect". Independent Online. 2 August 2005.

<http://www.iol.co.za/index.php?set id=1\&click id=2997\&art id=vn20050 $\underline{802063935205 C 505567>}$ Accessed on 20 March 2008.

${ }^{60}$ Solomon, J. "The danger of terrorist black holes in Southern Africa”. Terrorism Monitor 5/5. 2007. 4.

〈http://www.jamestown.org/terrorism.news/uploads/TM_005_005.pdf $>$

Accessed on 20 March 2008.

${ }^{61}$ Lefkowitz, J. "Terror's South African front". In the National Interest. 17 August 2005.

<http://www.inthenationalinterest.com/Articles/Vol3Issue33/Vol3Issue33Le fkowitz.html> Accessed on 19 March 2008.

${ }^{62} \mathrm{Da}$ Costa, W. "SA used to train Muslim terrorists". Independent Online. 14 March 2007.

<http://www.iol.co.za/index.php?set_id=1139\&art_id=vn200703140226163 92C896472> Accessed on 20 March 2008.

${ }^{63}$ Solomon, J. "New report of terrorist camp in South Africa". Terrorism Focus 4/12. 2007. 5.

<http://www.jamestown.org/terrorism/news/article.php?articleide=2373363

${ }^{64}$ Ibid.

$>$ Accessed on 20 March 2008.

${ }^{65}$ Rubin, B. "Will the big story of 2010 be a terrorist attack on the games?". Rubin Reports. 19 October 2009.

<http://wwwrubinreports.blogspots.com/2009/10/will-the-big-story-of-2010be-terrorist.html> Accessed on 21 October 2009.

${ }^{66}$ Solomon, H. Saudi Arabia: In the aftermath of terror. IIIS Occasional Paper No. 19/2009. Pretoria: International Institute for Islamic Studies, 2009, 1.

67 "SA too reactive". News24.com. 4 August 2005.

${ }^{68}$ Hofstatter, S, Govender S \& Naidoo, T. "World Cup terror alert SA accused of being slow to respond to warnings". Sunday Times. 30 May 2010. 1.

${ }^{69}$ Hofstatter, S, Govender, S \& Naidoo, T. "Terror camps in SA are gearing up for the World Cup". Sunday Times. 6 June 2010. 4.

${ }^{70}$ Holt, A. "South Africa in the war on terror". Terrorism Monitor 2/23. 2004. 1. <http://www.jamestown.org/terrorism/views/article_php?articleid=2368948

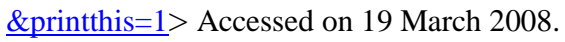

${ }^{71}$ Ibid.

${ }^{72}$ Nations hospitable to organized crime and terrorism. Washington DC: Federal Research Division, Library of Congress, 2003, 20-23.

${ }^{73}$ Bergman, R. The secret war with Iran: The 30-year covert struggle for control of a rogue state. Oxford: One World Publications, 2009, 193.

${ }^{74}$ Sandee op. cit., p. 3.

${ }^{75}$ Ibid., p. 7. 
${ }^{76}$ Sefara, M \& Fabricius, P. "City 2010 terror cell”. Weekend Argus. 11 October 2009. 1.

${ }^{77}$ Owino, W. “Al Qaeda operatives in Botswana, report claims”. Daily Nation. 1 October 2009. <http://www.nation.co.ke/News/africa/-/1066/523448//13rv5bez/-/index.html > Accessed on 1 September 2010.

${ }^{78}$ Hofstatter, Govender \& Naidoo, "World Cup terror alert ..." op. cit., p. 1.

${ }^{79}$ Hofstatter, Govender \& Naidoo, "Terror camps in SA ..." op. cit., p. 4.

${ }^{80}$ Ibid.

${ }^{81}$ Solomon, H. South Africa's ambiguous response to terrorism. CiPS E-Briefing Paper, No. 55/2008. Pretoria: Centre for International Political Studies, University of Pretoria, 2008, 2.

${ }^{82}$ Ibid., p. 2.

${ }^{83}$ Fabricius, P, Smillie, S, Gifford, G \& Reuters. "US still on terror threat in SA as buildings close". Pretoria News. 23 September 2009. 1.

${ }^{84}$ Basson, A. "Sizing up 2010 terror threat". Mail and Guardian. 26/2. 15-21 January 2010. 6.

85 "Mix response to Somali militancy claim". Voice of the Cape. 4 November 2009. <http://www.vocfm.co.za/index.php?section=newsandcategory=vocnews\&a

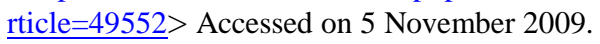

86 “Al Qaeda plot to attack 2010 football World Cup foiled in South Africa". Newstrack India. 14 October 2009.

<http://www.newstrackindia.com/newsdetails/128098> Accessed on 28 October 2009.

${ }^{87}$ Schanzer, J. "Pretoria unguarded". The Weekly Standard 12/35. 2007. 1. <http://www.weeklystandard.com/Content/Public/Article/000/000/013/6771 khfy.asp?pg=1> Accessed on 20 March 2008; "More SA names placed on terror list - Pahad". Independent Online. 31 January 2007.

<http://www.iol.co.za/index.php?set_id=1\&click_id=13\&art_id=qw1170276 483482B236> Accessed on 20 March 2008; Terdman, M. "Al Qaeda inroads in southern Africa”. PRISM Occasional Papers 2008. 3. $<$ http://www.eprism.org/images/PRISM_African_Papers_vol_2_no_1_Southern Africa March 08.pdf> Accessed on 20 March 2008. 